\title{
Analysis of a Brazilian green propolis from Baccharis dracunculifolia by HPLC-APCI-MS and GC-MS
}

\author{
Roberto Chang, ${ }^{1}$ Dorila Piló-Veloso, ${ }^{2}$ Sérgio A. L. Morais, ${ }^{1}$ Evandro A. Nascimento*,1 \\ ${ }^{1}$ Instituto de Química, Universidade Federal de Uberlândia, Av. João Naves de Ávila, 2160, \\ 38400-902 Uberlândia-MG, Brazil, \\ ${ }^{2}$ Departamento de Química, Universidade Federal de Minas Gerais, Av. Antônio Carlos, 6627, 31270-901 \\ Belo Horizonte-MG, Brazil,
}

\begin{abstract}
RESUMO: “Análise de uma própolis verde brasileira da Baccharis dracunculifolia por CLAE-ICPA-EM e CG-EM”. Os extratos em etanol e diclorometano de uma própolis verde de Baccharis dracunculifolia foram analisados por CLAE-ICPA-EM e CG-EM, respectivamente. A técnica de CLAE-EM-ICPA, no modo positivo, forneceu uma completa e inequívoca composição química da amostra de própolis verde. Ela serve como impressão digital para amostras diferentes de própolis. A composição do extrato em etanol consistiu fundamentalmente de ácido cinâmico e derivados, flavonóides, ácido benzóico e alguns benzoatos, aromáticos não hidroxilados, e ácidos e ésteres alifáticos, os quais são normalmente ignorados na literatura porque não absorvem luz UV. Os constituintes principais do extrato em diclorometano foram compostos prenilados, alcanos e terpenóides.
\end{abstract}

Unitermos: Baccharis dracunculifolia, Asteraceae, própolis, própolis verde, CLAE-EM-IQPA, CG-EM.

\begin{abstract}
Ethanol and dichloromethane extracts of a Brazilian green propolis from Baccharis dracunculifolia were analyzed by HPLC-APCI-MS and GC-MS, respectively. The HPLCAPCI-MS technique, at the positive mode, furnished a complete and unequivocal chemical composition of the green propolis sample. It serves as fingerprint for different propolis samples. The composition of the ethanol extract consisted mainly of cinnamic acid and derivatives, flavonoids, benzoic acid and a few benzoates, non-hydroxylated aromatics, and aliphatic acids and esters, which are normally not reported in the literature because they do not absorb UV light. The main constituents of the dichloromethane extract were prenylated compounds, alkanes and terpenoids.
\end{abstract}

Keywords: Baccharis dracunculifolia, Asteraceae, propolis, green propolis, HPLC-APCI-MS, GC-MS.

\section{INTRODUCTION}

Propolis is a resinous material produced by honeybees from vegetable resins, exudates, wax, pollen, leaf pieces, and self-secretion. It is used to seal and to protect the hive against heat, cold, wind, water, insects and microorganisms. (Ghisalberti, 1979; Rohwedder and Hausteen, 1987; Neto et al., 2002).

Propolis ethanol extracts have been used in the popular medicine for different purposes (Niraldo, et al., 2006; Soares et al., 2006; Tavares et al., 2006; Lemos et al., 2007; Missima and Sforcin, 2008; Simões et al., 2008). Flavonoids contained in European propolis were considered the constituents that had the beneficial action on the human organism. However in the last recent years many propolis other than the European ones have demonstrated therapeutic properties and they do not contain or contain insignificant amount of flavonoids (Park et al., 2000; Pereira et al., 2002; Longhini et al., 2007; Sousa et al., 2007).

Review publications report that over a hundred compounds were already identified in propolis (Greenaway et al., 1991; Marcucci, 1996; Lustosa et al., 2008). The propolis analysis is a very difficult task because their composition changes according to the region, season and existing flora in addition to the inherent difficulties associated to analysis of complex mixtures from vegetal sources. In spite of that, various researchers demonstrated that Baccharis dracunculifolia is the main vegetable source of Brazilian green propolis (Bankova et al., 1999; Bastos et al, 2000; Kumazawa et al., 2003; Park et al., 2003, 2004, 2005). Further, recently, a chemical marker for propolis from Baccharis dracunculifolia was proposed (Nascimento et al., 
2008).

By means of derivatization with BSTFA, GCMS analysis and a lot of reference compounds, over a hundred compounds could be identified in a propolis sample (Greenaway et al., 1991). The limitations of this technique reside on a more complex mixture after derivatization, the need of many rare reference compounds and the presence of non-volatile or underivatizable compounds that cannot be detected accordingly. Even using high temperatures (near 400 ${ }^{\circ} \mathrm{C}$ ), this technique has limitations (Neto et al., 2002)

Actually the tedious work on column fractionations and isolation of unknown compounds is giving place to high performance liquid chromatography (HPLC), which can provide a quickly separation of the components, quantification and information related to its UV spectrum. When coupled to Infrared (IR), Nuclear Magnetic Resonance (NMR) or Mass Spectrometry (MS), the HPLC can expand much more its analysis range. Especially the HPLC-MS technique is very useful because it avoids the limitations imposed by the UV detection while detecting also the molecules that do not absorb in the UV region. Today the HPLC-MS can use modern revolutionary techniques like ESI (electrospray ionization), APCI (atmospheric pressure chemical ionization), MALDI (matrix-assisted laser desorption/ ionization), etc. that volatilize organic molecules of low and high molecular weights having medium to high polarity (Hoffmann and Stroobant, 2001).

Some of these new techniques were recently employed on propolis analysis (Valcic et al., 1999; Midorikawa et al., 2001; Pietta et al., 2002; Kumazawa et al., 2003).

Due to the broad use in the medicine, actually the propolis investigation work is focused on ethanol extracts. Many model compounds were used to investigate samples of Brazilian propolis by HPLCESI-MS at the negative mode (Midorikawa et al., 2001). Based on the retention times and mass spectra of forty-one standards, these authors identified a lot of components in the propolis samples. Sawaya and collaborators also used the HPLC-ESI-MS at negative mode to identify eight markers in Brazilian propolis from different origins (Sawaya et al., 2004). Finally, using the same technique and others procedures, Kumazawa and collaborators compared propolis ethanol extracts from fourteen different countries (Kumazawa et al., 2004).

In the present work an attempt to expand the range of identification of the constituents of a propolis ethanol extract is presented. HPLC-APCI-MS at the positive mode was used and the identification was based on mass spectrometry, standards, UV spectrum, retention times, Kovat's indexes (Adams, 2001), the publications cited above and others (Nascimento and Bezzan, 2001; Neto et al., 2002; Nascimento et al., 2003a; Nascimento et al., 2003b; Nascimento et al., 2008; Negri et al., 2003).

Finally, a GC-MS investigation of the dichloromethane extract of the same propolis was also carried out in order to complement the data acquired from HPLC-APCI-MS.

\section{MATERIAL AND METHODS}

\section{Propolis sample}

The Santa Barbara Apiary located in the State of Minas Gerais supplied the sample of green propolis.

Table 1. Components of the EEP related to Figure 1.

\begin{tabular}{|c|c|}
\hline $\begin{array}{l}\text { Retention time } \\
(\mathrm{min})\end{array}$ & Compound \\
\hline 18.3 & ethyl cinnamate \\
\hline 20.2 & benzyl caffeate \\
\hline 22.1 & cinnamyl caffeate \\
\hline 24.0 & cinnamyl coumarate \\
\hline 25.8 & dihydrocinnamyl ferulate \\
\hline 27.1 & pinobanksin \\
\hline 29.6 & kaempferol \\
\hline 32.8 & 2,2-dimethyl-6-cromene-6-propenoic acid, 3-prenyl-p-coumaric acid \\
\hline 34.0 & methyl 2,2-dimethyl-6-chromene-propenoate \\
\hline 34.6 & diprenyl coumarate and n.i. $(\lambda 238,318 \mathrm{~nm})$ \\
\hline 35.5 & pinobanksin-3-acetate, kaempferide, dihydrokaempferide \\
\hline 36.0 & ermanin \\
\hline 36.6 & capillartemisin A \\
\hline 37.3 & (E)-3-[2,3-dihydro-2-(1-methylethenyl)-7-prenyl-5-benzofuranyl]-2-propenoic acid \\
\hline 38.2 & (E)-3-[2,3-dihydro-2-(1-hydroxy-1-methylethyl)-7-prenyl-5-benzofuranyl]-2-propenoic acid \\
\hline 38.9 & artepillin $\mathrm{C}$ \\
\hline 41.0 & n.i. $(\lambda 220,286 \mathrm{~nm})$ and n.i. $(\lambda 235,278 \mathrm{~nm})$ \\
\hline 41.9 & n.i. $(\lambda 262,318 \mathrm{~nm})$ \\
\hline
\end{tabular}

n.i.: not identified. 
It was collected in October and is representative of green propolis from Baccharis dracunculifolia as comproved by several analyses of green propolis samples from different regions. The ethanol extract of propolis (EEP) was obtained by mixing $3.00 \mathrm{~g}$ of sample with $10.0 \mathrm{~mL}$ of ethanol (Vetec brand, analytical grade, $95 \%$ ). The mixture was stirred for 24 hours away from light and then filtered and put into a freezer to separate the wax. A new filtration gave the studied extract. The dichloromethane extract of propolis (DEP) was obtained using another $3.00 \mathrm{~g}$ sample as above, except on that it was not put into the freezer for wax separation.

\section{Gas chromatography coupled to mass spectrometry (GC-MS)}

The analysis was performed in a gaseous chromatograph by Shimadzu, model GC-17A, equipped with a DB-5 30 meters capillary column, $0.25 \mathrm{~mm}$ of i.d., $0.25 \mu \mathrm{m}$ of film thickness, coupled to a mass spectrometer of same brand, model GCMS-QP5000, equipped with database of 330.000 mass spectra. The runs were performed under the following conditions: initial column temperature: $60{ }^{\circ} \mathrm{C}$, injector at $220{ }^{\circ} \mathrm{C}$ and interface at $240{ }^{\circ} \mathrm{C}$; column program: $60-240{ }^{\circ} \mathrm{C}$ at $3{ }^{\circ} \mathrm{C} / \mathrm{min}, 20 \mathrm{~min}$ at $240{ }^{\circ} \mathrm{C}$. $1 \mu \mathrm{L}$ of the sample of was injected under helium as carrier gas. The mass spectrometer worked under impact energy of $70 \mathrm{eV}$ and the mass detection included molecules from 40 to 450 Da.

High performance liquid chromatography coupled to mass spectrometry (HPLC-MS)

The HPLC runs were performed on a Shimadzu Class VP series liquid chromatograph equipped with diode array detector (PDA) and a reversed-phase CLCODS $30 \mathrm{~cm}$ column. The gradient conditions used were methanol HPLC grade and water/formic acid $(0.5 \%)$, starting with methanol $20 \%$ and after 40 minutes, $100 \%$ methanol, in a 60 minutes run. The injected volume was $20 \mu \mathrm{L}$.

The high performance liquid chromatography coupled to atmospheric pressure chemical ionization and mass spectrometry (HPLC-APCI-MS) analysis, at the positive mode, was carried out in a Quattro LCMicromass Mass Spectrometer. The chromatogram presented in this work (Figure 2) is the Total Ions Chromatogram, TIC.

\section{Identification of the propolis constituents}

The identification of the propolis components was based on a long and tedious work with standards, mass spectra library (Wiley 7), private UV spectra library, retention times, Kovat's indexes, and literature. As the compounds were not isolated and directly compared with standards, it is not warranted that they really are the assigned ones.

\section{RESULTS AND DISCUSSION}

Figure 1 presents the HPLC chromatogram of EEP. Low retention time components (less than 15 minutes), as chlorogenic, gallic, benzoic and caffeic acids, and vanillin are practically absent. This is not in agreement with HPLC results reported by Park and collaborators (Park et al., 2004) as well as Midorikawa and collaborators (Midorikawa et al., 2001). Both groups worked with ethanol extracts of green propolis

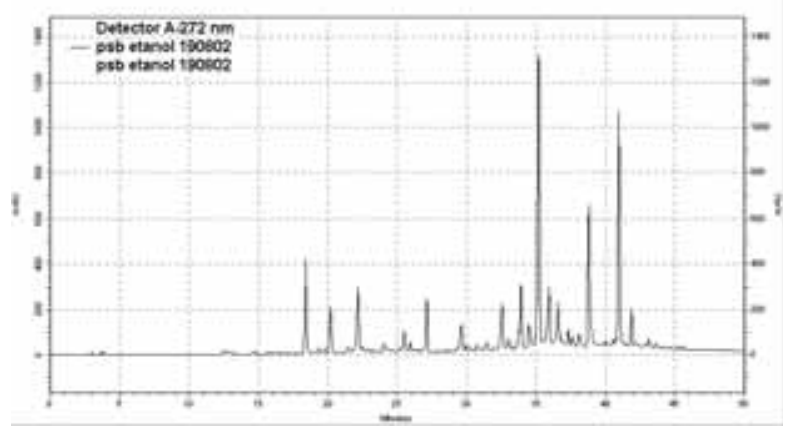

Figure 1. HPLC chromatogram of the ethanol extract of propolis.

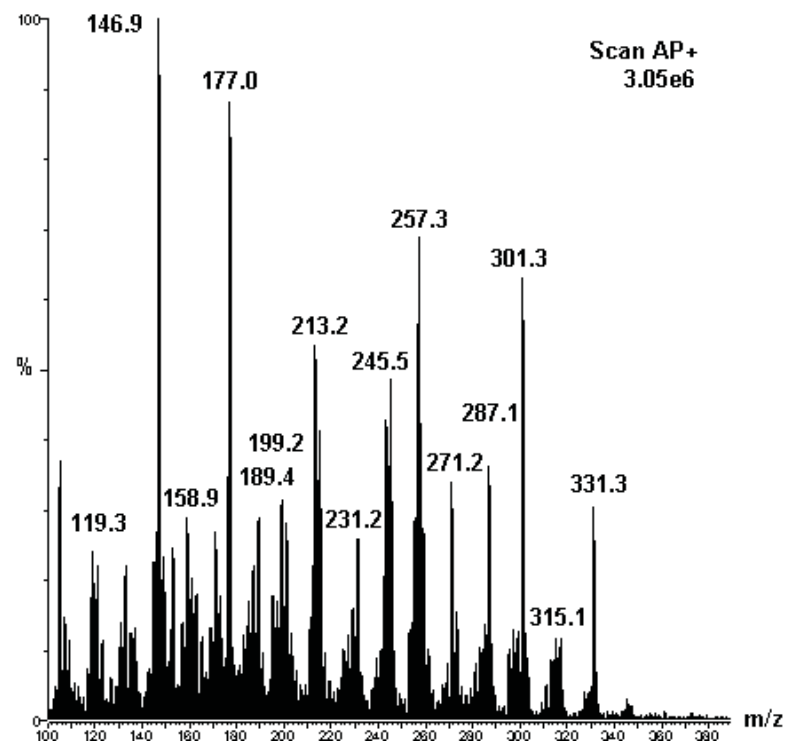

Figure 2. APCI-MS chromatogram of the ethanol extract of propolis.

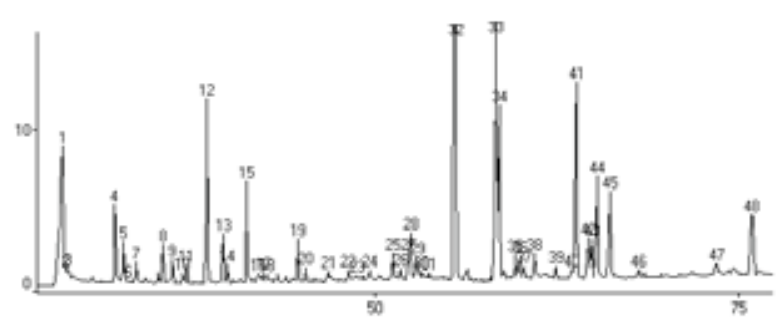

Figure 3. GC chromatogram of the dichloromethane extract of propolis. 
Table 2. Compounds of the EEP related to Figure 2.

\begin{tabular}{|c|c|c|c|}
\hline $\mathrm{N}^{\mathrm{O}}$ & $\mathrm{M}$ & Compound & $\%$ base-peak \\
\hline 1 & 330 & pinobanksin-3-acetate & 30 \\
\hline 2 & 316 & $\begin{array}{l}\text { (E)-3-[2,3-dihydro-2-(1-hydroxy-1-methylethyl)-7-prenyl-5-benzofuranyl]-2- } \\
\text { propenoic acid }\end{array}$ & 12 \\
\hline 3 & 314 & ermanin & 12 \\
\hline 4 & 312 & dihydrocinnamyl ferulate & 9 \\
\hline 5 & 302 & dihydrokaempferide & 9 \\
\hline 6 & 300 & artepillin $\mathrm{C}$, kaempferide, 4-hydroxi-3,5-diprenylcinnamic acid & 63 \\
\hline 7 & 298 & (E)-3-[2,3-dihydro-2-(1-methylethenyl)-7-prenyl-5-benzofuranyl]-2-propenoic acid & 12 \\
\hline 8 & 296 & cinnamyl caffeate & 13 \\
\hline 9 & 294 & methyl linoleate & 10 \\
\hline 10 & 286 & kaempferol & 35 \\
\hline 11 & 284 & acacetin, stearic acid & 14 \\
\hline 12 & 282 & oleic acid & 10 \\
\hline 13 & 280 & linoleic acid & 7 \\
\hline 14 & 272 & pinobanksin (chalcone) & 16 \\
\hline 15 & 270 & benzyl caffeate & 33 \\
\hline 16 & 268 & cinnamyl coumarate & 7 \\
\hline 17 & 260 & 14-acetoxy-trementone? & 10 \\
\hline 18 & 258 & 2',4',6'-triidroxi-chalcone & 27 \\
\hline 19 & 256 & palmitic acid, allyl 3-prenylcinnamate & 68 \\
\hline 20 & 254 & benzyl coumarate & 29 \\
\hline 21 & 252 & methyl-flavonol & 13 \\
\hline 22 & 244 & methyl 2,2-dimethyl-6-chromene-propenoate & 48 \\
\hline 23 & 242 & methyl miristate & 42 \\
\hline 24 & 240 & hydroxy-flavanone & 10 \\
\hline 25 & 238 & flavonol & 9 \\
\hline 26 & 232 & 3-prenyl-p-coumaric acid & 7 \\
\hline 27 & 230 & 2,2-dimethyl-6-cromene-6-propenoic acid & 26 \\
\hline 28 & 228 & miristic acid & 17 \\
\hline 29 & 226 & phenylethyl benzoate & 13 \\
\hline 30 & 224 & flavanone & 10 \\
\hline 31 & 218 & methyl 2,2-dimethyl-6-chromene-carboxylate & 6 \\
\hline 32 & 216 & n.i. & 10 \\
\hline 33 & 214 & methyl laurate & 42 \\
\hline 34 & 212 & n.i. & 53 \\
\hline 35 & 210 & dihydrochalcone & 15 \\
\hline 36 & 204 & 2,2-dimethylchromene-6-carboxilic acid, sesquiterpenes & 7 \\
\hline 37 & 202 & trementone & 13 \\
\hline 38 & 200 & lauric acid & 28 \\
\hline 39 & 198 & ethyl gallate & 31 \\
\hline 40 & 196 & methyl veratrate & 16 \\
\hline 41 & 194 & ferulic acid & 17 \\
\hline 42 & 190 & n.i. & 9 \\
\hline 43 & 188 & 5-(2,5-dimethylphenyl)-2(3H)-furanone & 28 \\
\hline 44 & 186 & methyl decanoate & 22 \\
\hline 45 & 184 & methyl gallate & 17 \\
\hline 46 & 182 & veratric acid & 12 \\
\hline 47 & 180 & caffeic acid & 8 \\
\hline 48 & 178 & 4-hydroxy-3-methoxycinnamaldehyde & 7 \\
\hline 49 & 177 & n.i. & 10 \\
\hline 50 & 176 & ethyl cinnamate & 87 \\
\hline 51 & 174 & 5-phenyl-pentadien-2,4-oic acid & 8 \\
\hline 52 & 172 & decanoic acid & 17 \\
\hline 53 & 170 & gallic acid & 27 \\
\hline 54 & 168 & vanillic acid & 13 \\
\hline 55 & 166 & dihydrocoumaric acid & 6 \\
\hline 56 & 164 & $p$-coumaric acid & 11 \\
\hline
\end{tabular}




\begin{tabular}{|c|c|c|c|}
\hline $\mathrm{N}^{\mathrm{o}}$ & $\mathrm{M}$ & Compound & $\%$ base-peak \\
\hline 57 & 162 & methyl cinnamate & 17 \\
\hline 58 & 160 & pimelic acid, ethyl glutarate & 20 \\
\hline 59 & 158 & isopentyl isobutirate, isopentyl butanoate, pelargonic acid & 28 \\
\hline 60 & 156 & n.i. & 13 \\
\hline 61 & 152 & 4-methoxy-benzoic acid & 24 \\
\hline 62 & 150 & dihydrocinnamic acid & 8 \\
\hline 63 & 148 & cinnamic acid & 23 \\
\hline 64 & 146 & ethyl succinate & 100 \\
\hline 65 & 144 & octanoic acid, isobutyl isobutirate, isobutyl butirate & 22 \\
\hline 66 & 142 & n.i. & 7 \\
\hline 67 & 136 & methyl benzoate & 13 \\
\hline 68 & 134 & malic acid & 12 \\
\hline 69 & 132 & ornitine & 23 \\
\hline 70 & 130 & isopentyl acetate, 2-methylbutyl acetate & 13 \\
\hline 71 & 126 & 6-methyl-hept-5-3-en-2-one & 6 \\
\hline 72 & 122 & benzoic acid & 12 \\
\hline 73 & 120 & acetophenone, 2,3-benzo-furan & 23 \\
\hline 74 & 118 & succinic acid & 25 \\
\hline 75 & 116 & isobutyl acetate & 7 \\
\hline 76 & 108 & benzyl alcohol & 12 \\
\hline 77 & 106 & benzaldehyde & 15 \\
\hline 78 & 104 & styrene & 37 \\
\hline
\end{tabular}

n.i.: not identified.

but the ethanol concentration was $80 \%$, which allows better dissolution of more hydrophilic compounds.

The peaks observed at the chromatogram belong practically to cinnamic acid derivatives and flavonoids (Table 1) and are in good agreement with the results obtained elsewhere (Pietta et al., 2002; Midorikawa et al., 2001). The prenylated compounds are very important constituents of green propolis (Vasconcelos, 2006; Pereira et al., 2202, Bankova et al., 1999).

Figure 1 is a good example for the HPLC technique constraints. Even using diode array detector the number of detected components is relatively low. This is due to different absorbance of the constituents (the apparatus is automatically calibrated according to the higher absorbance), no detection of compounds that do not absorb UV light, and peak overlapping.

Figure 2 presents the APCI-MS chromatogram of the EEP. Using the positive mode, the molecular ions appear as $[\mathrm{M}+1]$. Comparing Figure 2 with Figure 1, it is evident that this new technique gives much more information about the extract than the HPLC does. The number of detected compounds is incomparably greater and includes much more molecules, which absorb or not UV light. This chromatogram is the best indirect view of the extract composition and can be used as fingerprint of it. Certainly an APCI-MS chromatogram of another propolis ethanol extract will be different.

In Figure 2, the detected mass range goes from circa $100 \mathrm{Da}$ to $350 \mathrm{Da}$, confirming the absence of chlorogenic acids and other high molecular weight compounds as dimeric coniferyl acetate $(\mathrm{M}=442)$, propolis benzofurans $A(M=454)$ and $B(M=438)$, (E)-3-(2,3-dihydro-2-(1-methyethenyl)-7-prenyl-5benzofuranyl-2-propenoic acid $(\mathrm{M}=448)$, etc. and also the insignificant presence of small molecules (Midorikawa et al., 2001).

Table 2 shows the identified and not identified compounds corresponding to Figure 2, with the respective percentage (TIC). Only the compounds whose concentration was greater than $5 \%$ of the base peak were took in account.

For the first time a complete table showing the compounds present in the propolis ethanol extract is shown. The main constituents were cinnamic acid and derivatives, flavonoids, benzoic acid and a few benzoates, non-hydroxylated aromatics, and aliphatic acids and esters. The aliphatic compounds are normally not reported in the literature because they do not absorb UV light. It is very important to note that the presence of compounds that do not absorb UV light is significant. All of the compounds of Table 2 have already been reported in the propolis literature but a lot of them were not reported in ethanol extracts. Allyl 3-prenylcinnamate, which was isolated from chloroform extract of Baccharis dracunculifolia green propolis (Negri et al., 2003), has been recently proposed as chemical marker for this kind of propolis (Nascimento et al., 2008).

Figure 3 presents the GC-MS chromatogram of the DEP and Table 3 shows the identified and not identified volatile compounds of this extract. The main constituents are prenylated compounds (over $50 \%$ ) followed by terpenoids, which gives the special odor 
Table 3. Components of the DEP having concentration $\geq 0.27 \%$ (related to Figure 3).

\begin{tabular}{|c|c|c|c|c|}
\hline $\begin{array}{c}\text { Peak } \\
\text { number }\end{array}$ & $\begin{array}{l}\text { Retention time } \\
(\min )\end{array}$ & Molar mass & Compound & $\begin{array}{c}\% \\
\text { TIC }\end{array}$ \\
\hline $1+2$ & 28.76 & 150 & dihydrocinnamic acid & 7.55 \\
\hline 3 & 29.05 & 178 & dihydrocinnamic acid, ethyl ester & 0.56 \\
\hline 4 & 32.22 & 222 & $\begin{array}{l}\text { dihydrocinnamic acid, TMS ester (contamination by } \\
\text { BSTFA) }\end{array}$ & 2.14 \\
\hline 5 & 32.82 & 204 & trans-caryophillene & 0.94 \\
\hline 6 & 33.18 & 204 & trans-alfa-bergamotene & 0.39 \\
\hline 7 & 33.69 & 204 & aromadendrene & 0.54 \\
\hline 8 & 35.51 & 204 & germacrene-D & 0.75 \\
\hline 9 & 36.19 & 204 & bicyclogermacrene & 0.58 \\
\hline 10 & 36.87 & 204 & alfa-muurolene & 0.30 \\
\hline 11 & 37.15 & 204 & gamma-cadinene & 0.39 \\
\hline 12 & 38.54 & 204 & trans-nerolidol & 3.64 \\
\hline 13 & 39.68 & 220 & $(+)$-spathulenol & 0.93 \\
\hline 14 & 39.97 & 222 & globulol & 0.40 \\
\hline 15 & 41.23 & 188 & 5 -(2,5-dimethylphenyl)-2(3H)-furanone & 2.26 \\
\hline 16 & 42.07 & 220 & (-)-spathulenol & 0.41 \\
\hline 17 & 42.38 & 202 & desmethoxy encecalin & 0.33 \\
\hline 18 & 42.68 & 222 & alfa-cadinol & 0.34 \\
\hline 19 & 44.75 & 222 & 2-cis,6-trans-farnesol & 0.87 \\
\hline 20 & 45.29 & 220 & 14-hydroxy-alpha-humulene & 0.39 \\
\hline 21 & 46.86 & 164 & $p$-coumaric acid & 0.59 \\
\hline 22 & 48.21 & 236 & n.i. & 0.32 \\
\hline 23 & 48.86 & 218 & xanthorrihzol & 0.29 \\
\hline 24 & 49.70 & 220 & sesquiterpene alcohol & 0.40 \\
\hline 25 & 51,27 & & n.i. & 0.75 \\
\hline 26 & 51.83 & & n.i. & 0.34 \\
\hline 27 & 52.31 & 220 & sesquiterpene alcohol & 0.72 \\
\hline 28 & 52.52 & 230 & n.i. & 1.19 \\
\hline 29 & 52.95 & 308 & $p$-coumaric acid, di-tms ester (contamination by BSTFA) & 0.65 \\
\hline 30 & 53.30 & 256 & palmitic acid & 0.28 \\
\hline 31 & 53.74 & & n.i. & 0.36 \\
\hline 32 & 55.53 & 256 & allyl 3-prenylcinnamate & 40.28 \\
\hline 33 & 58.34 & 270 & prenylated compound & 5.35 \\
\hline 34 & 58.59 & 270 & prenylated compound & 3.47 \\
\hline 35 & 59.72 & & n.i. & 0.58 \\
\hline 36 & 59.97 & 270 & prenylated compound & 0.74 \\
\hline 37 & 60.31 & 254 & benzyl coumarate & 0.34 \\
\hline 38 & 61.03 & 272 & n.i. & 1.13 \\
\hline 39 & 62.47 & 268 & n.i. & 0.35 \\
\hline 40 & 63.56 & & n.i. & 0.31 \\
\hline 41 & 63.88 & 270 & prenylated compound & 6.32 \\
\hline 42 & 64.74 & & n.i. & 1.16 \\
\hline 43 & 64.98 & 310 & docosane & 1.06 \\
\hline 44 & 65.32 & & n.i. & 2.79 \\
\hline 45 & 64.24 & & n.i. & 3.08 \\
\hline 46 & 68.19 & & n.i. & 0.27 \\
\hline 47 & 73.50 & 338 & tetracosane & 0.64 \\
\hline 48 & 75.90 & 352 & pentacosane & 2.50 \\
\hline
\end{tabular}

n.i.: not identified.

to the green propolis. Allyl 3-prenylcinnamate is longer the more abundant and until today was detected only in the Baccharis dracunculifolia resin and therefore was proposed as chemical marker for this kind of propolis (Nascimento et al., 2008).

Taking in account that the ethanol and dichloromethane extracts solubilized $36.61 \%$ and 34.21 $\%$ of the propolis, respectively, a comparison of Tables 1,2 and 3 brings out interesting results. The volatile terpenoids and alkanes are present in the ethanol extract as minorities and were not considered in Tables 2 and 3. This extract fundamentally contains polar molecules 
that are not volatile. However, the analysis of volatile molecules by GC is very important to classify the aroma and plant sources of the propolis. Actually, the analysis of both extracts, EEP and DEP, are complementary for a better propolis chemical investigation.

\section{CONCLUSION}

The HPLC-APCI-MS technique, at the positive mode, provided a complete and unequivocal chemical composition of a green propolis sample. It serves as fingerprint for different propolis samples. The main constituents of the $95 \%$ ethanol extract of the green propolis from Baccharis dracunculifolia were cinnamic acid and derivatives, flavonoids, benzoic acid and a few benzoates, non-hydroxylated aromatics, and aliphatic acids and esters. The main constituents of the dichloromethane extract were prenylated compounds, alkanes and terpenoids. By means of this technique it was possible to detect the showed aliphatic compounds which are normally not reported in the literature because they do not absorb UV light.

\section{ACKNOWLEDGMENTS}

To Prof. Dr. Edson Rodrigues Filho (DQUFSCAR - São Carlos, Brazil) for the HPLC-APCI-MS analysis and discussion.

\section{REFERENCES}

Adams RP 2001. Identification of Essential Oil Components by Gas Chromatography/Quadrupole Mass Spectroscopy Allured Publishing Corp., Illinois.

Bankova V, Krasteva GB, Sforcin JM, Frete X, Kujumgieev A, Rodella RM, Popov S 1999. Phytochemical evidence for the plant origin of Brazilian propolis from São Paulo State. Z Naturforsch 54c: 401-405.

Bastos EM, Oliveira VDC, Soares AEE 2000. Characterization of the green propolis produced in Minas Gerais State, Brazil. Honeybee Sci 21: 179-180.

Ghisalberti EL 1979. Propolis: a review. Bee World 60: 5984.

Greenaway W, May J, Scaysbrook T, Whatley FR 1991 Identification by gas chromatography-mass spectrometry of 150 compounds in propolis. $Z$ Naturforsch 46c: 111-121.

Hoffmann E, Stroobant V 2001. Mass Spectrometry: Principles and Applications. John Wiley \& Sons, Chichester.

Kumazawa S, Yoneda M, Shibata I, Kanaeda J, Hamasaka T, Nakayama T 2003. direct evidence for the plant origin of Brazilian propolis by the observation of honeybee behavior and phytochemical analysis. Chem Pharm Bull 51: 740-742.

Kumazawa S, Hamasaka T, Nakayama T 2004. Antioxidant activity of propolis of various geographic origins. Food Chem 84: 329-339.

Lemos M, Barros MP, Sousa JPB, Silva Filho AA, Bastos JK, Andrade SF 2007. Baccharis dracunculifolia, the main botanical source of Brazilian green propolis, displays antiulcer activity. $J$ Pharm Pharmacol 59: 603-608.

Longhini R, Raksa SM, Oliveira ACP, Svidzinski TIE, Franco SL 2007. Obtenção de extratos de própolis sob diferentes condições e avaliação de sua atividade antifúngica. Rev Bras Farmacogn 17: 388-395.

Lustosa SR, Galindo AB, Nunes LCC, Randau KP, Rolim Neto PJ 2008. Própolis: atualizações sobre a química e a farmacologia. Rev Bras Farmacogn 18: 447-454.

Marcucci MC 1996. Propriedades biológicas e farmacêuticas dos constituintes da própolis. Quim Nova 19: 529536.

Midorikawa K, Banskota AH, Tezuka Y, Nagaoka T, Matsushige K, Message D, Huertas AAG, Kadota S 2001. Liquid chromatography-mass spectrometry analysis of propolis. Phytochem Anal 12: 366-373.

Missima F, Sforcin JM 2008. Green Brazilian propolis action on macrophages and lymphoid organs of chronically stressed mice. Evid-Based Compl Alt Med 5: 71-75.

Nascimento EA, Bezzan LCF 2001. Estudo da própolis do Triângulo Mineiro. Parte 1: Identificação dos constituintes solúveis em metanol/acetato de etila por CG-EM. Mensagem Doce 63: 7-15.

Nascimento EA, Morais SAL, Bezzan LCF, Chang R 2003a. Análise do resíduo insolúvel de uma própolis marrom do Triangulo Mineiro. Cie \& Eng 37: 84-87.

Nascimento EA, Bezzan LCF, Chang R, Morais SAL, Vallejo MCG 2003b. Comparação entre os constituintes da própolis e da resina de eucalipto provenientes do cerrado. Cie \& Eng 12: 15-18.

Nascimento EA, Chang R, Morais SAL, Piló-Veloso D, Reis DC 2008. Um marcador químico de fácil detecção para a própolis de alecrim-do-campo (Baccharis dracunculifolia). Rev Bras Farmacogn 18: 379-383.

Negri G, Salatino MLF, Salatino A 2003. Green propolis: unreported constituents and a novel compound from chloroform extracts. $J$ Apic Res 42: 39-41.

Neto FRA, Pereira, AS, Nascimento EA 2002. Lupeol alkanoates in Brazilian Propolis. Z Naturforsch $57 c$ : 721-726.

Niraldo P, Teixeira C, Martins R, Scremin A, Dirsch VM, Vollmar AM, Abreu SRL, Solange SL, Marcucci MC 2006. Evaluation of the analgesic and antiinflammatory effects of a Brazilian green propolis. Planta Med 72: 899-906.

Park YK, Ikegaki M, Alencar SM, Moura FF 2000. Evaluation of Brazilian propolis by both physicochemical methods and biological activity. Honeybee Sci 21: 85-90.

Park YK, Paredes-Guzmán J, Aguiar CL, Fujiwara F 2003. Estudo das própolis que contém Artepillin C. Mensagem Doce 74: 9-16.

Park YK, Paredez-Guzman JF, Aguiar CL, Alencar SM, Fujiwara FY 2004. Chemical constituents in Baccharis dracunculifolia as the main botanical origin of southeastern Brazilian propolis. J Agr Food Chem 52: 1100-1103.

Park YK, Fukuda I, Ashida H, Nishiumi S, Yoshida KI, Daugsch A, Sato HH, Pastore GMJ 2005. Suppressive effects of ethanol extracts from propolis and its main botanical origin on dioxin toxicity. J Agr Food Chem 53: 10306-10309.

Pereira AS, Neto FRA, Seixas FRMS 2002. Própolis: 100 anos 
de pesquisa e suas perspectivas futuras. Quim Nova 25: 321-326.

Pietta PG, Gardana C, Pietta AM 2002. Analytical methods for quality control of propolis. Fitoterapia 73 (Suppl 1): $\mathrm{S} 7-\mathrm{S} 20$.

Rohwedder D, Havsteen HB 1987. Propolis. Taschenbuch Verlags $\mathrm{GmbH}$, Berlin.

Sawaya ACHF, Tomazela DM, Cunha IBS, Bankova VS, Marcucci MC, Custódio AR, Eberlin MN 2004. Electrospray ionization mass spectrometry fingerprinting of propolis. Analyst 129: 739-744.

Simões CC, Araújo DB, Araújo RPC 2008. Estudo in vitro e ex vivo da ação de diferentes concentrações de extratos de própolis frente aos microrganismos presentes na saliva de humanos. Rev Bras Farmacogn 18: 84-89.

Soares AKA, Carmo GC, Quental DP, Nascimento DF, Bezerra FAF, Moraes MO, Moraes MEA 2006. Avaliação da segurança clínica de um fitoterápico contendo Mikania glomerata, Grindelia robusta, Copaifera officinalis, Myroxylon toluifera, Nasturtium officinale, própolis e mel em voluntários saudáveis. Rev Bras Farmacogn 16: 447-454.

Sousa JPB, Furtado NAJC, Jorge R, Soares AEE, Bastos JK 2007. Perfis físico-químico e cromatográfico de amostras de própolis produzidas nas microrregiões de Franca (SP) e Passos (MG), Brasil. Rev Bras Farmacogn 17: 85-93.

Tavares JP, Martins IL, Vieira AS, Lima FAV, Bezerra FAF, Moraes MO, Moraes MEA 2006. Estudo de toxicologia clínica de um fitoterápico a base de associações de plantas, mel e própolis. Rev Bras Farmacogn 16: 350-356.

Valcic S, Montenegro G, Mujica AM, Avila G, Franzblau S, Singh MP, Maiese WM, Timmermann BN,1999. Phytochemical, morphological, and biological investigations of propolis from Central Chile. $Z$ Naturforsch 54c: 406-416.

Vasconcelos Y 2006. Própolis contra câncer. Revista Pesquisa da FAPESP 129: 72-74. 